\title{
Diabetic Crises in Children Treated with Small Doses of Intramuscular Insulin
}

\author{
JOHN MOSELEY
}

British Medical fournal, 1975, 1, 59-61

\begin{abstract}
Summary
A new regimen for the management of diabetic crises in children using small doses of intramuscular insulin and generous amounts of intravenous fluids has been devised. Insulin dosage was calculated from the patient's weight and was independent of the degree of hyperglycaemia. Minimum demands were made upon the laboratory.
\end{abstract}

\section{Introduction}

Recent work has been carried out in Oxford on the management of adults in diabetic coma with small doses of intramuscular insulin (Alberti et al., 1973). Such treatment is based on the knowledge that the optimum level of plasma insulin to promote glucose transport lies between 20 and $200 \mathrm{mU} / 1(\mu \mathrm{U} / \mathrm{ml})$. Alberti et al. found that an initial injection of 20 units of insulin given intramuscularly followed by 5 units given at hourly intervals produced and maintained these optimum levels in severly ill patients. The therapeutic response was excellent. Furthermore, such a regimen prevented the drop in plasma potassium which is a source of anxiety in these cases. Similar results can be obtained more rapidly by the intravenous route, but the method is complicated because of the need for equipment to promote a continuous infusion to counteract the rapid destruction of insulin by the liver. Subcutaneous injection results in slow absorption with the danger of depot formation and a swing to hypoglycaemia later. Injecting insulin intramuscularly minimizes the risk of depot formation, and the rate of absorption is greatly increased. A trial was conducted using a modification of the Oxford regimen for the management of diabetic crises in children.

\section{Patients and Methods}

Over a period of seven months 12 children aged 17 months to 14 years were admitted in severe diabetic crisis; two were admitted twice. They were all severely ill and in need of intravenous rehydration.

\section{CLINICAL DETAILS}

Eight of the children were known diabetics and four were new cases (table I). Infection was the precipitating factor in nine, and of the remainder one child came in with acute obstruction, one with pronounced hepatomegaly due to poor control, and one had simply reduced progressively her dose of insulin. All were very ill and needed immediate intravenous therapy to relieve dehydration. Six were semi-conscious and one was in deep coma. The severity of the ketoacidosis is shown by the $\mathrm{pH}$ levels

Paediatric Department, St. Mary's Hospital, Portsmouth JOHN MOSELEY, M.B., F.R.C.P., Consultant Paediatrician recorded on admission in 12 cases (see table II). In three patients it was below 7 and in only one was it over $7 \cdot 1$. This caused considerable respiratory distress and relief of this symptom was one of the criteria of recovery. The plasma glucose levels varied from 24.4 to $74.9 \mathrm{mmol} / \mathrm{l}(440$ to $1350 \mathrm{mg} / 100 \mathrm{ml}$ ), but in only one patient was the blood urea level over $16.6 \mathrm{mmol} / \mathrm{l}(100 \mathrm{mg} /$ $100 \mathrm{ml}$ ). The E.C.G. monitor showed pronounced peaking of the $T$ waves on admission on four occasions.

\section{GENERAL MANAGEMENT}

Generous amounts of physiological saline $(0.154 \mathrm{~mol} / \mathrm{l})$ were given as a first priority to relieve dehydration and promote tissue perfusion. The flow rate was determined on clinical grounds, but as a general guide $500 \mathrm{ml}$ can be infused at the following rates: in two to three hours for children under 2 years, in one hour for those aged 2-5 years, and in 15 to 30 minutes for those over 6 years of age. Subsequently these rates are cut to one-third.

Potassium chloride was added in amounts to give $10 \mathrm{mmol}$ ( $\mathrm{mEq}$ ) per $500 \mathrm{ml}$ of physiological saline as soon as the first dose of insulin was given, provided the E.C.G. monitor showed no peaking of $T$ waves.

Sodium bicarbonate was given cautiously as a $4 \cdot 2 \%$ solution if the $\mathrm{pH}$ was below $7 \cdot 1$ and the signs of ketoacidosis severe.

As soon as plasma glucose levels had fallen to around $11 \cdot 1$ $\mathrm{mmol} / 1(200 \mathrm{mg} / 100 \mathrm{ml}) 4.2 \%$ glucose in physiological saline diluted five times $(0.031 \mathrm{~mol} / \mathrm{l})$ replaced the normal saline infusion.

A nasogastric tube was passed soon after admission, the stomach contents were aspirated, and gastric lavage with warm water was performed. Fluids by mouth were introduced gradually as the patient's condition improved.

Intramuscular Insulin.-Soluble insulin was injected intramuscularly as soon as the diagnosis was confirmed or within an hour of starting the infusion if the patient was a known diabetic. The injections were repeated at hourly intervals until the acute symptoms of ketoacidosis had been overcome and the plasma glucose had fallen below $11.1 \mathrm{mmol} / \mathrm{l}$. When this point was reached intramuscular insulin was stopped and insulin was injected subcutaneously every four hours. At the same time appropriate amounts of carbohydrate were given using the established method described by Lawrence (1945). The dose of intramuscular insulin was calculated entirely upon the patient's weight and was independent of the degree of hyperglycaemia. The initial dose was $0.25 \mathrm{U} / \mathrm{kg}$ body weight followed by $0.1 \mathrm{U} / \mathrm{kg}$ hourly until ketoacidosis was relieved and plasma glucose had fallen below $11.1 \mathrm{mmol} / 1$.

Assessment.-A blood sample was sent to the laboratory on admission and again two hours after the initial dose of insulin. Plasma glucose and electrolytes were estimated. A linear projection of the fall in glucose concentration over this period enabled us to predict fairly accurately the time at which levels would return to normal. Blood $\mathrm{pH}$ was measured in the ward laboratory. Hourly monitoring of the plasma glucose was undertaken at the bedside using Dextrostix, and continuous observation on the E.C.G. monitor gave valuable information in controlling potassium deficit. Urine samples were tested routinely for glucose and ketones when available. The usual clinical observations were recorded with particular reference to the degree of dehydration, the level of consciousness, and the extent of Kussmaul respiration. 
TABLE I-Clinical Details of 12 Children admitted with Diabetic Crises

\begin{tabular}{|c|c|c|c|c|c|c|c|c|c|c|c|}
\hline $\begin{array}{l}\text { Case } \\
\text { No. }\end{array}$ & Precipitating Factor & $\begin{array}{c}\text { Age } \\
\text { (Years) }\end{array}$ & $\begin{array}{c}\text { Weight } \\
\text { (kg) }\end{array}$ & $\begin{array}{c}\text { Normal Dose } \\
\text { of Insulin } \\
\text { (U) }\end{array}$ & Pulse/min & $\underset{/ \min }{\text { Respirations }}$ & $\underset{\left({ }^{\circ} \mathbf{C}\right)}{\text { Temperature }}$ & $\begin{array}{c}\text { Blood } \\
\text { Pressure } \\
(\mathrm{mm} \mathrm{Hg})\end{array}$ & $\begin{array}{l}\text { Mental } \\
\text { State }\end{array}$ & $\begin{array}{l}\text { Fluid } \\
\text { Loss }\end{array}$ & $\begin{array}{c}\text { Kussmaul } \\
\text { Respiration }\end{array}$ \\
\hline $\begin{array}{l}1 \\
2 \\
3 \\
4 \\
5\end{array}$ & $\begin{array}{l}\text { Tonsillitis } \\
\text { Tonsillitis } \\
\text { Virus meningitis } \\
\text { Poor control } \\
\text { Virus pneumonia } \\
\text { Haemolytic }\end{array}$ & $\begin{array}{l}9 \frac{1}{2} \\
13^{2} \\
11 \\
13 \\
13 \frac{1}{2}\end{array}$ & $\begin{array}{l}37 \\
45 \\
41 \\
32 \\
37\end{array}$ & $\begin{array}{c}44 \\
64 \\
\text { New case } \\
28 \\
30\end{array}$ & $\begin{array}{l}145 \\
140 \\
120 \\
180 \\
152\end{array}$ & $\begin{array}{l}45 \\
++ \\
30 \\
52 \\
44\end{array}$ & $\begin{array}{l}37 \\
\text { Low } \\
34 \cdot 2 \\
35\end{array}$ & $\begin{array}{c}140 / 100 \\
90 / 70 \\
150 / 100 \\
125 / 80 \\
120 / 75\end{array}$ & $\begin{array}{l}\text { Precoma } \\
\text { Precoma } \\
\text { Precoma } \\
\text { Restless } \\
\text { Precoma }\end{array}$ & $\begin{array}{r}++ \\
++ \\
++ \\
++ \\
++\end{array}$ & $\begin{array}{l}++ \\
+++ \\
+++ \\
+++ \\
+++\end{array}$ \\
\hline $\begin{array}{l}6 \\
7 \\
8\end{array}$ & $\begin{array}{l}\quad \text { streptococcal } \\
\text { U.R.T.I. } \\
\text { Influenza B } \\
\text { Acute obstruction } \\
\text { Pneumococcal } \\
\text { U.R.T.I. }\end{array}$ & $\begin{array}{l}1 \frac{1}{2} \\
11 \\
14 \\
5\end{array}$ & $\begin{array}{r}9 \\
29 \\
32 \\
16\end{array}$ & $\begin{array}{c}\text { New case } \\
22 \\
10 \\
\text { New case }\end{array}$ & $\begin{array}{l}170 \\
120 \\
100 \\
128\end{array}$ & $\begin{array}{l}40 \\
28 \\
20 \\
18\end{array}$ & $\begin{array}{l}37 \\
36 \\
36 \\
36 \cdot 5\end{array}$ & $\begin{array}{l}135 / 100 \\
120 / 90\end{array}$ & $\begin{array}{l}\text { Coma } \\
\text { Precoma } \\
\text { Alert } \\
\text { Precoma }\end{array}$ & $\begin{array}{r}++++ \\
++ \\
+ \\
++++\end{array}$ & $\begin{array}{c}+++ \\
++ \\
\mathrm{Nil}^{+} \\
\mathrm{Nil}\end{array}$ \\
\hline $\begin{array}{l}9 \\
10 \\
11 \\
12\end{array}$ & $\begin{array}{l}\text { Tonsillitis } \\
\text { Reduced insulin } \\
\text { Unknown } \\
\text { Otitis media } \\
\text { Unknown }\end{array}$ & $\begin{array}{r}12 \\
14 \\
15 \\
15 \\
5\end{array}$ & $\begin{array}{l}39 \\
60 \\
42 \\
42 \\
18\end{array}$ & $\begin{array}{c}30 \\
24 \\
26 \\
30 \\
\text { New case }\end{array}$ & $\begin{array}{l}140 \\
125 \\
130 \\
140 \\
160\end{array}$ & $\begin{array}{l}36 \\
36 \\
24 \\
22 \\
30\end{array}$ & $\begin{array}{l}35 \\
36 \cdot 4 \\
36 \\
38 \\
36\end{array}$ & $\begin{array}{c}120 / 90 \\
120 / 80 \\
120 / 90 \\
60 /\end{array}$ & $\begin{array}{l}\text { Precoma } \\
\text { Restless } \\
\text { Restless } \\
\text { Restless } \\
\text { Precoma }\end{array}$ & $\begin{array}{r}++ \\
++ \\
++ \\
+++ \\
++\end{array}$ & $\begin{array}{r}+++ \\
+++ \\
++ \\
++ \\
+++\end{array}$ \\
\hline
\end{tabular}

U.R.T.I. = Upper respiratory tract infection.

TABLE II-Results of Biochemical Studies. Values are shown on Admission and Two Hours after First Dose of Insulin

\begin{tabular}{|c|c|c|c|c|c|c|c|c|c|c|c|c|}
\hline \multirow{2}{*}{ Case No. } & \multicolumn{2}{|c|}{$\begin{array}{l}\text { Plasma Glucose } \\
(\mathrm{mmol} / \mathrm{l})\end{array}$} & \multicolumn{2}{|c|}{$\begin{array}{c}\text { Plasma Bicarbonate } \\
(\mathrm{mmol} / \mathrm{l})\end{array}$} & \multicolumn{2}{|c|}{$\begin{array}{l}\text { Plasma Sodium } \\
(\mathrm{mmol} / \mathrm{l})\end{array}$} & \multicolumn{2}{|c|}{$\underset{(\mathrm{mmol} / \mathrm{l})}{\text { Plasma Potassium }}$} & \multirow{2}{*}{$\frac{\begin{array}{c}\text { Plasma } \\
\text { Urea } \\
(\mathrm{mmol} / \mathrm{l})\end{array}}{0 \mathrm{~h}}$} & \multicolumn{2}{|c|}{$\begin{array}{l}\text { Plasma Chloride } \\
(\mathrm{mmol} / 1)\end{array}$} & \multirow{2}{*}{$\begin{array}{c}\frac{c}{\text { Blood }} \text { pH } \\
0 \mathrm{~h}\end{array}$} \\
\hline & $0 \mathrm{~h}$ & $2 \mathrm{~h}$ & $\mathrm{Oh}$ & $2 \mathrm{~h}$ & $\mathrm{Oh}$ & $2 \mathrm{~h}$ & $\mathrm{Oh}$ & $2 \mathrm{~h}$ & & $\mathrm{Oh}$ & $2 \mathrm{~h}$ & \\
\hline $\begin{array}{l}1 \\
2 \\
3 \\
4 \\
5 \\
6 \\
7 \\
8 \\
9 \\
10 \\
11 \\
12\end{array}$ & $\begin{array}{l}37 \cdot 7 \\
47.2 \\
25 \cdot 0 \\
26 \cdot 6 \\
25.3 \\
32 \cdot 2 \\
38.9 \\
24 \cdot 4 \\
74.9 \\
33.3 \\
26.6 \\
28 \cdot 0 \\
30.5 \\
26.1\end{array}$ & $\begin{array}{r}15 \cdot 0 \\
36 \cdot 1 \\
14 \cdot 4 \\
20 \cdot 5 \\
21 \cdot 1 \\
17 \cdot 2 \\
15 \cdot 5 \\
12 \cdot 2 \\
33 \cdot 6 \\
21 \cdot 7 \\
9 \cdot 7 \\
20 \cdot 0 \\
22 \cdot 8 \\
14 \cdot 4\end{array}$ & $\begin{array}{r}6 \\
4 \\
4 \\
5 \\
7 \\
6 \\
10 \\
14 \\
9 \\
5 \\
7 \\
5 \\
3 \\
4\end{array}$ & $\begin{array}{r}5 \\
5 \\
7 \\
5 \\
6 \\
6 \\
7 \\
15 \\
12 \\
8 \\
8 \\
4 \\
5 \\
8\end{array}$ & $\begin{array}{l}127 \\
140 \\
124 \\
125 \\
133 \\
139 \\
138 \\
143 \\
138 \\
126 \\
138 \\
137 \\
142 \\
137\end{array}$ & $\begin{array}{l}130 \\
146 \\
133 \\
128 \\
137 \\
151 \\
142 \\
147 \\
154 \\
137 \\
142 \\
144 \\
147 \\
136\end{array}$ & $\begin{array}{l}6 \cdot 1 \\
6 \cdot 6 \\
4 \cdot 6 \\
4.5 \\
5 \cdot 6 \\
4 \cdot 7 \\
5.9 \\
3 \cdot 4 \\
5.9 \\
6 \cdot 7 \\
5 \cdot 2 \\
4 \cdot 7 \\
6 \cdot 0 \\
3 \cdot 6\end{array}$ & $\begin{array}{l}5 \cdot 7 \\
6 \cdot 0 \\
3 \cdot 3 \\
4 \cdot 9 \\
6 \cdot 4 \\
4 \cdot 3 \\
5 \cdot 5 \\
4 \cdot 0 \\
4 \cdot 1 \\
6 \cdot 8 \\
5 \cdot 3 \\
3 \cdot 7 \\
4 \cdot 7 \\
3.9\end{array}$ & $\begin{array}{r}8 \cdot 6 \\
12.6 \\
9.0 \\
6 \cdot 6 \\
9 \cdot 0 \\
12.5 \\
7.1 \\
5.8 \\
19.4 \\
9.5 \\
5.6 \\
6.6 \\
8.1 \\
6.0\end{array}$ & $\begin{array}{r}92 \\
99 \\
94 \\
96 \\
100 \\
109 \\
100 \\
104 \\
94 \\
98 \\
111 \\
103 \\
105 \\
112\end{array}$ & $\begin{array}{l}109 \\
104 \\
101 \\
104 \\
111 \\
125 \\
112 \\
114 \\
118 \\
110 \\
112 \\
112 \\
106 \\
111\end{array}$ & $\begin{array}{l}7.01 \\
6.95 \\
7.07 \\
7.01 \\
6.97 \\
7.02 \\
7.28 \\
7.05 \\
6.92 \\
7.05 \\
7.04 \\
7.04\end{array}$ \\
\hline
\end{tabular}

Conversion: SI to Traditional Units-Glucose: $1 \mathrm{mmol} / 1 \simeq 18 \mathrm{mg} / 100 \mathrm{ml}$. Urea: $1 \mathrm{mmol} / 1 \simeq 6 \mathrm{mg} / 100 \mathrm{ml}$. Electrolytes: $\mathrm{mmol} / 1 \equiv \mathrm{mEq} / \mathrm{l}$.

\section{Results}

Once the initial anxiety caused by abandoning a long-established practice of giving a large initial dose of insulin when confronted by a desperately ill ketoacidotic patient had been overcome the calculation of insulin dosage caused no problem. It was this anxiety which prompted the administration of double the initial scheduled dose to our first patient. This was the only case (case 1) where the plasma glucose fell below $5.0 \mathrm{mmol} / 1(90 \mathrm{mg} / 100 \mathrm{ml})$. Case 3 presented a problem in both initial diagnosis and assessment owing to a combination of virus meningoencephalitis and diabetic coma. The persistence of semi-coma raised fears of hypoglycaemia despite the reassuring Dextrostix readings and three doses of insulin were omitted in the hourly schedule. As soon as the intramuscular injections were resumed, however, the biochemical control was smoothly established over three hours. It is with this type of problem that the flexibility of the method proves valuable. When acidotic breathing persisted after relief of hyperglycaemia, as in case 9 , intramuscular insulin was continued after the intravenous infusion had been changed to dextrose saline until the symptoms were relieved.

The fall in plasma glucose after the start of hourly intramuscular insulin over a period of two hours lent support to the adequacy of the small doses (table II). The absence of hypoglycaemia and hypokalaemia in any patient treated on the regimen was probably related to the small doses used.

The rapid initial intravenous infusion did not produce signs of venous overload. The importance of rapid restoration of fluid and electrolytes is universally accepted and provides considerable relief even before the initial dose of insulin. In case 2 a technical difficulty reduced the rate of flow and the delay in rehydration was reflected in the poor response of the hyperglycaemia in the first two hours of therapy.

The danger of giving too much physiological saline was considered. The only patient who suffered from hypernatraemia, however, was a 5-year-old girl (case 8) who presented with non-ketotic diabetic coma. Three hours after admission she seemed to be making excellent progress. Her plasma glucose had fallen from 74.9 to $33.6 \mathrm{mmol} / \mathrm{l}(1350$ to $605 \mathrm{mg} / 100 \mathrm{ml}$ ) and she was sufficiently conscious to ask for a drink. At that stage she had received $925 \mathrm{ml}$ of saline. The plasma sodium had risen from 138 to $154 \mathrm{mmol} / \mathrm{l}$. She was still very dehydrated, however, and the drip was speeded up so that she received another $370 \mathrm{ml}$ in the next hour. She lapsed into unconsciousness. It was only then that the biochemical report was received and the drip changed to half-strength physiological saline $(0.077$ $\mathrm{mol} / \mathrm{l}$.). The sodium level rose to $160 \mathrm{mmol} / \mathrm{l}$ at this stage and it required $300 \mathrm{ml}$ of half-strength saline to correct the hypernatraemia. After this she made a complete recovery. During the period when only 1.5 units of intramuscular insulin was being given hourly the control of hyperglycaemia proved no problem. The plasma glucose had fallen from the initial level of 74.9 $\mathrm{mmol} / 1(1350 \mathrm{mg} / 100 \mathrm{ml})$ to $14.4 \mathrm{mmol} / 1(260 \mathrm{mg} / 100 \mathrm{ml})$ within five hours of admission.

A 17-month-old infant (case 5) was completely collapsed and unconscious on admission. He received $500 \mathrm{ml}$ of physiological saline in the first two and a half hours without ill effect though the plasma sodium did rise to $151 \mathrm{mmol} / \mathrm{l}$. Altogether he was given $850 \mathrm{ml}$ in seven and a half hours. It seems unlikely that the amount of saline advocated will cause trouble in a straightforward case. Once again small hourly doses of intramuscular insulin, only 1 unit in this case, controlled the hyperglycaemia smoothly. The plasma glucose fell from $32 \cdot 2$ to $9 \cdot 7 \mathrm{mmol} / 1$ (580 to 175 $\mathrm{mg} / 100 \mathrm{ml}$ ) and the $\mathrm{pH}$ rose from 6.97 to 7.3 in six and a half hours. At this stage he was alert and crying.

The control of plasma potassium caused no anxiety. No addition of potassium to the infusion was made until the E.C.G. monitor had been set up and the first dose of insulin given. In 
TABLE III-Amounts of Intramuscular Insulin and Intravenous Fluids given to each Patient

\begin{tabular}{|c|c|c|c|c|c|c|c|}
\hline \multirow[b]{3}{*}{ Case No. } & \multicolumn{3}{|c|}{ Intramuscular Insulin (U) } & \multicolumn{4}{|c|}{ Intravenous Fluids } \\
\hline & \multirow[b]{2}{*}{ Initial Dose } & \multirow[b]{2}{*}{ Hourly Dose } & \multirow[b]{2}{*}{ Total Dose } & \multicolumn{3}{|c|}{ Potassium Chloride } & \multirow[b]{2}{*}{$\begin{array}{c}\text { Total Dose of } 4 \cdot 2 \% \\
\text { Sodium } \\
\text { Bicarbonate (ml) }\end{array}$} \\
\hline & & & & $\begin{array}{l}\text { Time of Start of } \\
\text { KCl after First } \\
\text { Insulin Dose } \\
\text { (h) }\end{array}$ & $\begin{array}{l}\text { Total at lh } \\
(\mathrm{ml})\end{array}$ & $\underset{(\mathrm{ml})}{\text { Total at } 5 \mathrm{~h}}$ & \\
\hline $\begin{array}{r}1 \\
2 \\
3 \\
4 \\
5 \\
6 \\
7 \\
8 \\
9 \\
10 \\
11 \\
12\end{array}$ & $\begin{array}{c}20 \\
12 \\
10 \\
12 \\
10 \\
2 \cdot 5 \\
6 \\
8 \\
3 \\
8 \cdot 5 \\
12 \\
10 \\
10 \\
5\end{array}$ & $\begin{array}{l}5 \\
5 \\
5 \\
5 \\
4 \\
1 \\
2 \cdot 6 \\
3 \\
1 \cdot 5 \\
3 \cdot 5 \\
5 \\
4 \\
4 \\
1 \cdot 5\end{array}$ & $\begin{array}{l}30 \\
37 \\
30 \\
32 \\
34 \\
7 \cdot 5 \\
13 \cdot 5 \\
14 \\
10 \cdot 5 \\
33 \\
37 \\
18 \\
22 \\
8 \cdot 5\end{array}$ & $\begin{array}{c}\text { Immediately } \\
4 \\
\text { Immediately } \\
1 \\
1 \\
1 \frac{1}{2} \\
\text { Immediately } \\
\text { Immediately } \\
\text { None given } \\
5 \\
1 \\
4 \\
\text { Immediately } \\
\text { Immediately }\end{array}$ & $\begin{array}{r}1040 \\
300 \\
1160 \\
1400 \\
635 \\
170 \\
635 \\
800 \\
600 \\
1000 \\
625 \\
500 \\
600 \\
500\end{array}$ & $\begin{array}{r}2340 \\
1820 \\
2200 \\
2300 \\
2875 \\
650 \\
2000 \\
1425 \\
1350 \\
3500 \\
1775 \\
1360 \\
1750 \\
1300\end{array}$ & $\begin{array}{l}\mathrm{Nil} \\
120 \\
160 \\
\mathrm{Nil} \\
500 \\
72 \\
\mathrm{Nil} \\
\mathrm{Nil} \\
\mathrm{Nil} \\
300 \\
450 \\
100 \\
200 \\
100\end{array}$ \\
\hline
\end{tabular}

TABLE IV-Response to Treatment. Times are measured from Start of Intravenous Saline Infusion

\begin{tabular}{|c|c|c|c|c|c|}
\hline \multirow[b]{2}{*}{$\begin{array}{l}\text { Case } \\
\text { No. }\end{array}$} & \multicolumn{2}{|c|}{ Relief of Hyperglycaemia } & \multicolumn{2}{|c|}{ Relief of Acidosis } & \multirow{2}{*}{$\begin{array}{l}\text { Time of Start } \\
\text { of Lawrence } \\
\text { Regimen } \\
\text { (h) }\end{array}$} \\
\hline & $\begin{array}{l}\text { Plasma } \\
\text { Glucose } \\
(\mathrm{mmol} / \mathrm{l})\end{array}$ & $\underset{(\mathrm{h})}{\text { Time }}$ & $\begin{array}{c}\text { Time of } \\
\text { Normal } \\
\text { Respiration } \\
\text { (h) }\end{array}$ & pH & \\
\hline $\begin{array}{r}1 \\
2 \\
3 \\
4 \\
5 \\
6 \\
7 \\
8 \\
9 \\
10 \\
11 \\
12\end{array}$ & 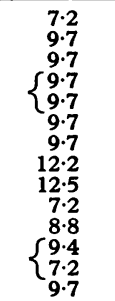 & $\begin{array}{l}3 \\
5 \\
8 \\
5 \\
6 \\
6 \frac{1}{2} \\
3 \frac{1}{2} \\
2 \\
7 \\
6 \frac{1}{2} \\
7 \\
4 \\
4 \frac{1}{2} \\
6\end{array}$ & $\begin{array}{l}5 \\
3 \\
5 \\
5 \\
9 \\
6 \frac{1}{2} \\
5 \frac{1}{2} \\
\\
8 \\
5 \\
3 \\
1 \\
4\end{array}$ & $\begin{array}{l}7 \cdot 34 \\
7 \cdot 38\end{array}$ & $\begin{array}{c}8 \\
7 \\
9 \\
5 \\
9 \\
7 \frac{1}{2} \\
5 \frac{1}{2} \\
3 \\
6 \frac{1}{2} \\
10 \\
8 \frac{1}{2} \\
4 \\
4 \frac{1}{2} \\
6\end{array}$ \\
\hline
\end{tabular}

Conversion: SI to Traditional Units-

Glucose: $1 \mathrm{mmol} / 1$ $18 \mathrm{mg} / 100 \mathrm{ml}$.

cases $2,5,8$, and 9 the $\mathrm{T}$ waves were peaked and the addition of potassium was delayed (table III). In case 11 the delay on the patients first admission was caused by difficulty in setting up the E.C.G. monitor because of her restlessness. It was the only case where the level fell as low as $2.6 \mathrm{mmol} / \mathrm{l}$ with flattened $\mathrm{T}$ waves. No clinical effects were otherwise observed.

The cautious addition of $4 \cdot 2 \%$ sodium bicarbonate to the infusion was permitted when the $\mathrm{pH}$ was below $7 \cdot 1$ and the respiratory distress severe. It was used on nine occasions without any complication (table III). It was added to the saline and we ensured that it was given over several hours.

The speed with which the patient was restored to a fair measure of normality is shown in table IV. The average time taken for over-coming hyperglycaemia, and for stopping Kussmaul respiration in the 12 cases in which it was recorded, was five hours. The average time before Kussmaul respiration stopped was unduly long, however, as a result of the second admission of case 4 in which hyperventilation persisted because of the association of virus pneumonia. The total dose of intramuscular insulin varied between 7.5 and 37 units with an average of 23 units. In most cases the rapid initial infusion rate target was reached.

\section{Discussion}

Though the effective level of plasma insulin for dealing with glucose transport and relieving ketoacidosis was shown to lie between 20 and $200 \mathrm{mU} / 1(\mu \mathrm{U} / \mathrm{ml})$ (Sönksen et al., 1972) some workers remain unhappy about the safety of relying on small insulin doses when dealing with diabetic coma (Froesch, 1973). More recent work using a continuous intravenous infusion of insulin in a series of 38 patients treated in four different centres (Page et al., 1974), however, has confirmed that these modest levels are effective. The use of the intravenous route has certain obvious advantages. The therapeutic level is rapidly reached irrespective of the vagaries of absorption from subcutaneous or intramuscular sites, and the danger of depot formation and hypoglycaemia are eliminated. Nevertheless, even if we accept the suggestion that it can be administered by no more complicated equipment than a paediatric drip set (Kidson et al., 1974) there is the problem of preparing the insulin solution. Intramuscular insulin, on the other hand, is safely injected by a nurse, and the relative delay in reaching a therapeutic level is of no practical consequence. The acceptance of the small dose regimen eliminates the risk of depot formation and hypoglycaemia. We have found it effective even when dealing with a 17-month-old infant in severe coma.

I thank Professor K. G. M. M. Alberti for his advice and continued interest; the resident medical staff of the paediatric department of St. Mary's Hospital and the nursing staff, who co-operated enthusiastically in carrying out this project; Dr. H. Miller and Dr. J. Durant and their colleagues in the biochemistry department for their interest and support; and Dr. G. M. Lewis and Dr. M. Hardman who allowed patients under their care to be included in this trial.

\section{References}

Alberti, K. G. M. M., Hockaday, T. D. R., and Turner, R. C. (1973). Lancet, 2, 515 .

Froesch, E. R. (1973). Lancet, 2, 1330.

Kidson, W., et al. (1974). British Medical fournal, 1, 691.

Lawrence, R. D. (1944). The Diabetic Life, 13th edn., p. 122. London, Churchill.

Page, M. Mc. B., et al. (1974). British Medical fournal, 1, 687.

Sönksen, P. H., et al. (1972). Lancet, 2, 155. 